\title{
Economics
}

The Open-Access, Open-Assessment E-Journal

Vol. 14, 2020-15 | June 3, 2020 | http://dx.doi.org/10.5018/economics-ejournal.ja.2020-15

\section{The direct and indirect impacts of liberal immigration policies on the United States' economy}

\section{Geiguen Shin}

\begin{abstract}
Many studies have suggested that stringent labor protections and higher labor costs can limit foreign direct investment (FDI) in host countries. This would imply that the decisions of foreign firms are sensitive to the degree of flexibility in the labor market in the U.S. The U.S. has a steady stream of immigration, which has preserved the stability of the labor supply for the U.S. market. This makes the U.S. a good test case for the relationship between immigration and FDI because it is not only the largest host for FDI but also has the largest immigrant population in the world in absolute terms and is experiencing a significant reduction in labor supply and an increase in the minimum cost of labor. Utilizing a timeseries analysis of data from 1970 to 2016, this study suggests that expansive immigration policies directly increase FDI inflows in the U.S. and indirectly increase FDI inflows by lowering labor costs and securing a stable supply of labor.
\end{abstract}

JEL $\quad$ F16 J15

Keywords Foreign direct investment; immigration policy; labor cost

Author

Geiguen Shin, School of Public Policy, Georgia Institute of Technology, Georgia, USA; School of Public Administration and Public Policy, Kookmin University, Seoul, South Korea, geiguen@gmail.com

Citation Geiguen Shin (2020). The direct and indirect impacts of liberal immigration policies on the United States' economy. Economics: The Open-Access, Open-Assessment E-Journal, 14 (2020-15): 1-29. http://dx.doi.org/10.5018/economics-ejournal.ja.2020-15

Received June 19, 2019 Published as Economics Discussion Paper July 12, 2019 Revised May 6, 2020 Accepted May 19, 2020 Published June 3, 2020

(c) Author(s) 2020. Licensed under the Creative Commons License - Attribution 4.0 International (CC BY 4.0) 


\section{Introduction}

Many countries have traditionally used a locational model for their economic development policies, which takes into account how government policies affect the locational decisions of business and industry. Thus, these governments seek to design economic development policies that would promote firms to locate in their countries by lowering costs for the factors of production and providing tax incentives (Williams, 1967; Plaut and Pluta, 1983). Studies of this issue have largely focused on effects on foreign direct investment (FDI). Scholars of FDI have likewise explored the major determinants of firms' investments and their locational decisions in relation to a certain country.

Empirical studies of FDI have observed factors such as marketability, economic size, and institutional capacities as possible FDI determinants for a given host country (Chan, 1995; Ancharaz, 2003). In particular, studies of FDI have indicated that poor labor market conditions are a critical obstacle to FDI inflows (e.g., Naylor and Santoni, 2003; Owen, 2013). Further, managers of multinational enterprises have expressed a strong preference to consider investing in regions with high labor availability and low labor costs (Arpan, 1981). For manufacturing in particular, labor costs are an important factor for FDI inflows in the host country (Owen, 2013). While previous works have expanded knowledge of the influence of labor market conditions on multinational corporations' location decision, the causal effects of labor costs on FDI have not been adequately explored. The critical impact of the domestic labor supply on labor costs leads this study to pay close attention to the impact of international migration, which could increase the labor supply and lower wages.

This correlation of factors is important for the U.S. market. Not only has the U.S. been much less supportive of labor markets than other advanced economies, it is also the host of more immigrants, in absolute terms, than any other country. Moreover, the case of the U.S. is interesting in that it has the most flexible labor market among the OECD countries, with lower labor costs, low levels of unionization, and less regulation, and is experiencing a steady decline in labor force participation, beginning in the mid-1960s. A recent report by the White House Council of Economic Advisors (CEA) indicates that the U.S. has one of the lowest rates of prime-age male labor force participation in the OECD countries (2016). Further, the CEA indicates that the U.S. government spends $0.1 \%$ of U.S. GDP on policies to encourage active labor markets, far below that of the OECD average, $0.6 \%$ of GDP. This action could be expected to reduce labor supply and increase the minimum cost of labor. However, the U.S. has become the destination of steady net immigration, which forms a significant part of the labor supply and thus has helped keep labor costs in the U.S. market down. It is reasonable to suggest that because the U.S. is the largest host country of FDI and has the highest immigrant population in the world but suffers from among of the highest labor costs worldwide, immigration could lead to potential increases in FDI inflows in the U.S. by improving the flexibility of labor markets.

In this study, I suggest that in the U.S., less restrictive immigration policies directly increase FDI inflows and indirectly increase FDI inflows by lowering potential labor costs and securing a stable labor supply. The remainder of this research proceeds as follows. In the next section, I briefly discuss the existing literature on the relationship between immigration and FDI. The following section suggests a theoretical link between immigration and FDI. The next two 
sections outline the research design and present the results of a time-series analysis over 19702016. Possible implications of the findings are discussed in the conclusion.

\section{$2 \quad$ Literature on the Link between Immigration Policy and FDI}

FDI is defined as international capital flows that entail a minimum $10 \%$ ownership stake of a business unit in a country other than the source of the funds and with the intention of establishing a new subsidiary/branch, acquiring a controlling share of an existing firm, or participating in a joint venture, among others (Moosa, 2002). Such an investment extends a firm's corporate network over national and political boundaries, allowing it to exercise ownership over resources transferred abroad, including capital, equipment, engineering expertise, and managerial and marketing skills (Liu, 1997).

The literature on immigration policy includes studies of the effects of immigration of capital markets and economic returns. Borjas (1999, p. 67) argues that "Entrepreneurs thinking about starting up new firms will find it more profitable to open them in immigrant areas." This suggests that immigration increases the return to capital, and capital will naturally flow to areas where the returns are highest, including areas with higher immigrant populations. Gaston and Nelson (2002) have reported that the impact of FDI on the labor market can be explained by the effects of immigration. Kim (2006) argues that labor and FDI move in the same direction, and thus that movements of labor will affect FDI flows.

Immigrant communities have been investigated in relation to investment in a region by foreign firms. Foad (2012) argues that immigrant networks lower risk for foreign investment thanks to their increased information flows within the market. He suggests that growth in an immigrant community leads to new FDI from the native countries of the immigrants. As more immigrants arrive, firms from the sending country will invest more in the host country, following the immigrants through connections made. Gould (1994) also argues that immigrants' links to their home country induce firms from their birth-country to invest. Javorcik et al. (2011) suggest that FDI in the U.S. is positively associated with the presence of migrants from the sending country because immigrants create a strong social network that connects them to their country of origin. These findings suggest that host countries can benefit economically from the ethnic diversity created by immigration.

Murat and Pistoresi (2006) argue that networks of Italian emigrants abroad significantly promote inward and outward bilateral FDI. However, they also find that the overall influence of immigrants is, at best, marginal. Baker and Benjamin (1997) find no significant relationship between Asia-Pacific immigrants and FDI inflows in Canada, but Gao (2000) indicates that Chinese immigrants have a positive association on inbound FDI in the U.S. Other scholars identify that different types of immigrants have different effects on inward capital flows. For instance, Ivlevs (2006) examines the relationship between international high- and low-skilled labor on capital flows. He finds that an inflow of high-skilled labor always leads to higher accompanying FDI inflows in the host countries. Baldwin and Venables (1994) also find that changes in the stock of high-skilled workers affects returns on FDI because current and expected wage differentials influence emigration decisions among high-skilled workers. 


\section{Immigration Policy of the Federal Government and FDI Inflows}

Both static and dynamic neoclassical models in macroeconomics suggest that more liberal international migration can allocate an efficient global workforce by increasing international integration of markets driven by migrant networks (Combes et al., 2005; Klein and Ventura, 2007; Rauch and Trindade, 2002). For example, ethnic networks are positively associated with international trade, not only because an increase in migrant population increases the demand for its home-country products but also because the stock of migrants reduce information costs and contracting costs (i.e., trade costs) by using their indigenous knowledge and information related to their home countries (Combes et al., 2005; Gould, 1994). The positive effects of the socioeconomic enrichment of immigration networks, however, is not limited to bilateral trade. Because trade itself refers exclusively to transactions across countries, we can expect that FDI is influenced by the networked ethnic activity (Bernard and Moxnes, 2018).

Larger ethnic networks also create sources of consumption. They have a substantial impact on FDI inflows not only by creating cultural diversity and socioeconomic enrichment in the host countries but also by increasing social capital and innovation through interpersonal ties within each given ethnic group (Gheasi and Nijkamp, 2017). A growing body of research on the effectiveness of immigration has demonstrated that growth in immigrant populations leads to growth in FDI largely because of the positive impact of ethnic networks connected to the immigrants' native country (e.g., Bernard and Moxnes, 2018; Foad, 2012). These ethnic networks can effectively lower political risk and reduce asymmetric information because "immigrants serve as a bridge over which capital may more easily flow between their native and current countries” (Foad, 2012, p. 238). Gould (1994, p. 302) also suggests that "immigrant links to the home country include knowledge of home-country markets, language, preferences, and business contacts.” Immigration networks are positively associated with FDI inflows, not only because an increase in migrant population increases the demand for home-country products but because migrants reduce information gaps and contracting costs by providing indigenous knowledge and information related to their home countries (Combes et al., 2005; Javorcik et al., 2011). Earlier work suggests that more expansive immigration policies would increase FDI due to the increased expected return to foreign firms obtained by accessing immigrants' experience, information, and social capital.

While many of the skilled immigrants to the U.S. in recent years have come from China and India, the major source countries for investment of assets and plants in the U.S. are from Western Europe and Australia (Foad, 2012; Shin, 2018), accounting for more than 70\% of all foreign-owned the real annual book value of gross property, plant, and equipment. Regardless of where a multinational corporation is domiciled, however, it is important to note it is a rational actor that is pursuing profit maximization (Shin, 2018). Thus, firms from Western Europe and Australia are not likely to make their investment decisions based on immigrants' countries of origin. Indeed, rational firms can be expected to be interested in all immigrants who form part of a competitive workforce in U.S. markets.

Despite the relative breadth of data available to assess immigration in relation to foreign firms' investment decisions, little attention to the link between a government's immigration policy and its FDI inflows. That is, while many studies suggest that the number of migrants is correlated with FDI increases, they do not examine whether a country's immigration policy 
relates the foreign firms' investment decisions. The volume and composition of immigration flows are significantly influenced by restrictions in immigration policy (Mayda, 2010; Ortega and Peri, 2009). Rational foreign firms take policy changes into account that would affect longterm migration volumes, rather than making investment decisions based on short-term changes in numbers of immigrants. Indeed, rational firms prefer deliberate governments because they provide a more predictable and steadier policy environment (Jensen, 2003; Li, 2009). It is also important to note that "direct investment generally requires a long-term focus and interactions with a diverse group of economic agents from suppliers, workers and consumers to government officials" (Javorcik et al., 2011, p. 231). Thus, it is important to see the impact of changing immigration policies on FDI against a background of long-term expectations. Furthermore, despite the important probable link between labor costs and FDI and between immigration and FDI, the effects of immigration policy on FDI flows mediated by the stock of labor in the host country have not been examined. In addition, the cross-sectional impacts of immigration on FDI inflows have been studied, but there has been little work on its impacts on the U.S., the world's largest immigrant destination and host of the world's largest amount of FDI. This research examines whether more expansive immigration policies can motivate foreign firms to invest in the U.S.

For these reasons, I posit the following testable hypothesis for a direct relationship between immigration policy and FDI.

Hypothesis 1: More liberal immigration policies attract more FDI.

Infosys Technologies Ltd., a multinational information technology service company operating in the U.S. and headquartered in Bangalore, India, employs more than 8,500 foreign workers who are in the U.S. on H-1B visas. The H-1B is a non-immigrant visa, provided for under the Immigration and Nationality Act, section 101(a)(15)(H), which is intended for foreign guest workers working in specialty occupations. ${ }^{1}$ Although Infosys Technologies Ltd. report that they need skilled foreign labor to remain competitive and fill positions for which there are not enough American workers, such as programmers, engineers, and chip designers, their intention was to cheaply increase their skilled personnel by hiring foreign aliens (Preston and Bajaj, 2011).

The example shows the trade-off between expansive immigration law and foreign firms' utility in terms of labor cost. Major macro-determinants of firms' investment decisions include market size, labor cost, and government policy (Ali and Guo, 2005). ${ }^{2}$ Although the U.S. is the world's largest market for foreign firms, it has been less able to attract foreign firms due its lack of highly skilled labor and high costs. As Lucas (1990) points out, economic theory predicts that labor and capital flow in positive directions. Li and Resnick (2003) argue that large increases in labor costs suppress expected returns, leading FDI investors to shy away from the potential investment in the U.S. Figure 1 shows that the overall trend over time between labor costs and FDI inflows have moved in a negative direction. The U.S. experienced increased FDI inflows and decreased labor costs during the mid-1990s and early 2000s.

1 Detailed definitions are available at the U.S. Citizenship and Immigration Services website (http://www.uscis.gov/eir/visa-guide/h-1b-specialty-occupation/h-1b-visa).

2 Ali and Guo $(2005$, 24) classify FDI inflows into three categories, micro-, macro, and strategic determinants. 


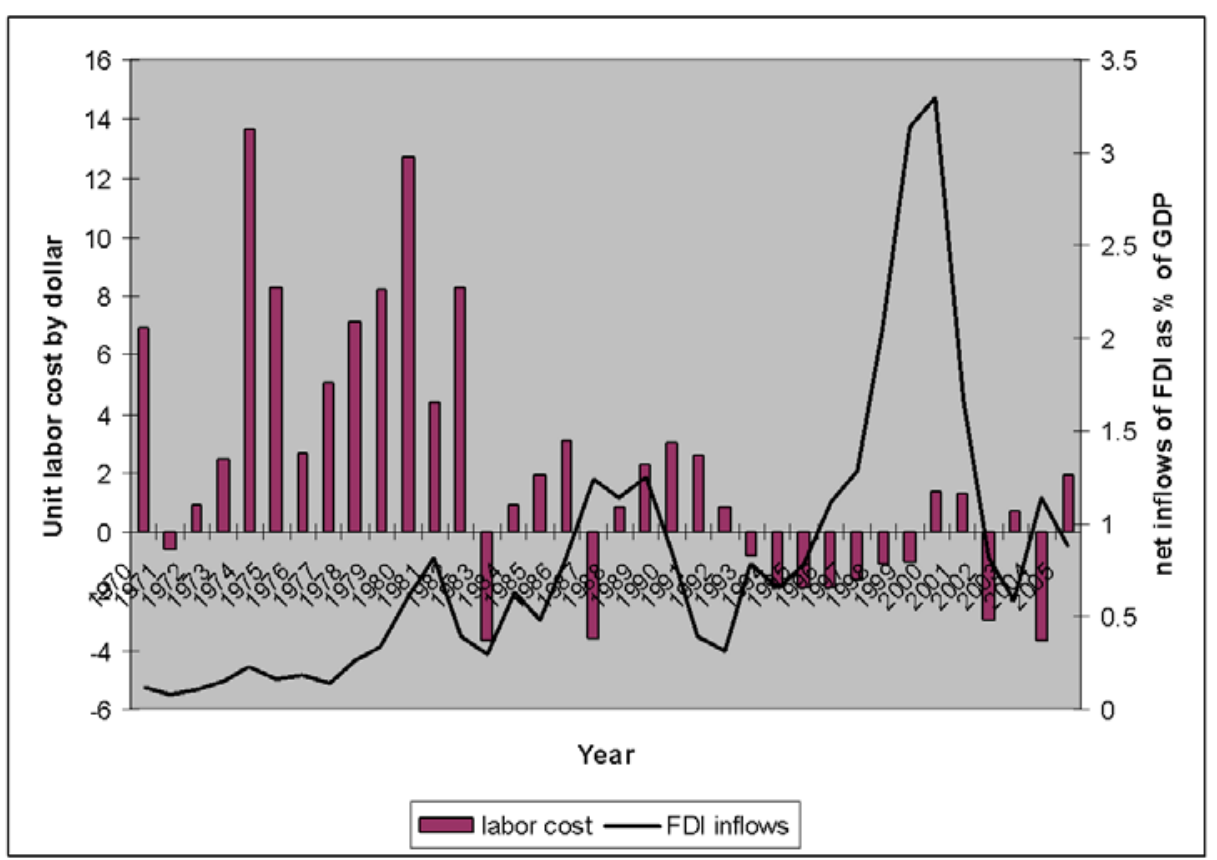

Source: Bureau of Economic Analysis and Bureau of the Labor Statistic

If the relationship between labor cost and FDI inflows is so vital, what can lower labor costs in the U.S.? Some scholars suggest that expansive immigration policy entices immigrants, who support the labor supply in local labor markets (e.g., Borjas, 1999; Wong, 2006). Ivlevs (2006) suggests that "actual international labor flows are determined by changes in national regulation (such as the imposition of immigration quotas), and not solely by wage differential in sending and receiving countries” (Ivlevs, 2006, p. 3). Theoretical discussion of immigration policy indicates that, as they are the principal economic beneficiaries of a liberal policy that would lead to the expansion of the labor pool, employers can hold wages down in the context of a more liberal policy even when native workers are available (Slaughter, 2003; Wong, 2006). Similarly, Borjas (1999) demonstrates that expansive immigration policies stimulate the entry of large numbers of less-skilled workers, which has the effect of lowering wages among competing domestic workers (Borjas, 1999).

The positive link between immigration policy and investment decisions by foreign firms to bring FDI can be clarified by recalling that firms are rational in nature and pursue activities intended to result in profit maximization. Fry (1983) points out that international investors explicitly watch how restrictive immigration policies function and how regulations are adopted, modified, or eliminated. Moosa (2002) suggests that firms make their decision whether to invest using data from four major categories: the market forces that guide the country's economic activity; the types of investment the government is seeking; actual laws, policies, and regulations and those in development; and cost-benefit analysis. Moosa (2002) finds, for example, that the growth of U.K. FDI to the U.S. since the 1980s is due to the relatively unrestrictive immigration policy toward inward FDI. Survey respondents from foreign firms 
provide critical evidence that labor costs are heavy in the decisions of both manufacturing and service companies to locate overseas, and thus they pay closer attention to the laws or regulations that may affect the labor market. ${ }^{3}$ When foreign firms expect the wage-down effect from increased immigrants, they pay closer attention to changes in immigration policy.

In short, U.S. immigration policy and FDI inflows are both important as separate phenomena, but they are interconnected as well. A new immigration policy that is intended to increase immigration would produce a more flexible labor market, which in turn would attract foreign investors. Although the federal government must consider other policies when taking action to impact FDI, particularly those that provide financial incentives, such as reduced corporate tax rates, grants, and preferential loans, immigration policy is nevertheless a critical factor for firms as they make their investment decisions. All else being equal, expansive immigration policy can be expected to increase FDI in the U.S. due to the larger stable supply of laborers in the market. Taken as a whole, then, I posit the following two hypotheses:

Hypothesis 2: More liberal immigration policies tend to reduce labor costs.

Hypothesis 3: More liberal immigration policies indirectly increase FDI inflows by lowering labor costs.

This paper expects that more expansive immigration policies attract FDI. In addition to this direct effect, it is expected that more expansive immigration policies indirectly lead to increased FDI inflows through downward pressure on labor costs, as shown in Figure 2.

Figure 2: Conceptual Linkage between Immigration Policy and FDI Inflows

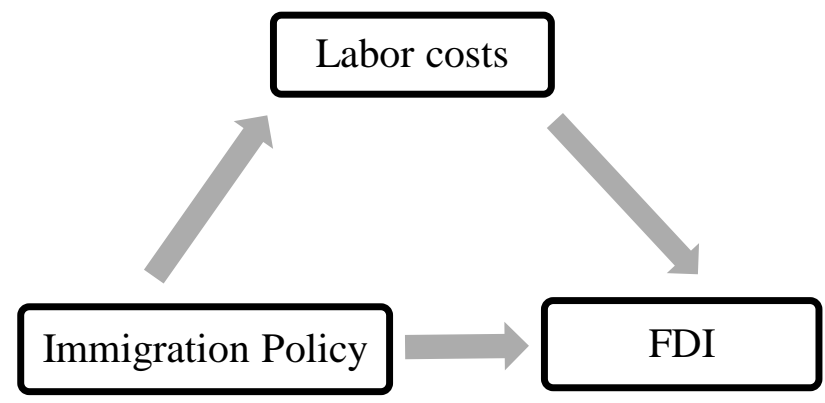

\section{$4 \quad$ Data and Measurement}

The data for the analysis are drawn from the period between 1970 and 2016 in the U.S. This is largely determined by data availability. They are time series data. Most data of the data used to measure immigration policies were extracted from Migration Policy Institute and Federation for American Immigration Reform. Other data, including information on FDI inflows, is found in

\footnotetext{
3 The World Bank. 2002. Foreign Direct Investment Survey. Washington, DC: The World Bank Group
} 
both the 2017 International Financial Statistics, published by the International Monetary Fund, and the 2017 World Development Indicator, compiled by the World Bank. Descriptive statistics for each variable are shown in Table 1.

Table 1:. Descriptive Statistics

\begin{tabular}{lccccc}
\hline & Observations & Mean & Std. Dev. & Minimum & Maximum \\
\hline FDI Inflows & 47 & 1.083 & 0.852 & 0.075 & 3.404 \\
Refugee ceiling per capita & 37 & 0.036 & 0.018 & 0.022 & 0.102 \\
Immigration law & 47 & 0.191 & 0.398 & 0 & 1 \\
Labor cost & 47 & 90.677 & 17.118 & 51.1 & 111.2 \\
Corporate tax & 47 & 0.394 & 0.060 & 0.34 & 0.492 \\
Regulation & 47 & 124858.6 & 35234.66 & 54834 & 185053 \\
Government expenditures & 47 & 15.745 & 1.051 & 13.996 & 18.069 \\
Economic growth & 47 & 1.795 & 1.981 & -3.624 & 6.334 \\
Market size & 47 & 19.375 & 0.141 & 19.139 & 19.594 \\
Interest rate & 47 & 4.106 & 2.365 & 0.585 & 8.720 \\
Inflation & 47 & 4.133 & 2.926 & 0.119 & 13.509. \\
Trade openness & 47 & 21.220 & 5.383 & 13.730 & 30.885 \\
Union membership & 47 & 16.681 & 4.786 & 10.7 & 27.4 \\
\hline
\end{tabular}

\section{Dependent Variable}

Because the article focuses on total foreign capital invested in the U.S., the dependent variable is net inflows of FDI, including equity capital, reinvestment of earnings, other long-term capital, and short-term capital, as shown in the balance of payments, giving a foreign investor a management interest (10\% or more of voting stock) in an enterprise. Rational firms are not likely to relocate their plants and capitals to a region where they have already invested, so long as the cost of maintaining their production facilities do not exceed benefits. Indeed, most foreign firms are mobile ex ante, but relatively immobile ex post (Vernon, 1971). This suggests that the FDI series is not constant across time. Thus, I model FDI as a percentage of GDP. FDI data are taken from the Bureau of Economic Analysis.

\section{Independent Variables}

Because immigration policy is not considered to increase or allow illegal immigrants, this study focuses on legal immigration. To create more reliable measures for immigration policy, I 
employ the annual refugee admission ceiling and, alternatively, a year dummy for major immigration reform, as well as the number of lawful permanent residents per capita.

First, while legal immigrants and non-immigrants must be allowed entry under immigration laws, the number of immigrants measured cannot adequately capture changes in immigration policy because the real number of immigrants cannot exactly reflect the migration flows that the targeted policies are intended to produce. The number of immigrants in $1930(14,204,100)$ under the quota system was much higher than the number of immigrants in $1970(9,619,300)$, when the quota system was no longer in force. Instead of using the number of immigrants, therefore, I choose the annual refugee admission ceiling. Although refugees are admitted on humanitarian grounds, refugee policy is usually considered a general immigration policy that reflects national interests (Whelan, 1983). Further, presidents have exercised substantial decision authority over the number of refugees to be admitted each year since Congress passed the Refugee Act in 1980 (Rodriguez, 2010). This suggests that analyzing the ceiling is a more straightforward way of determining the degree of restrictiveness of immigration policy at the national level because the changing quota of refugees admitted to the U.S. mirrors the overall pattern of U.S. immigration policy. To measure the effect of policy changes on migration flows, many studies have used the number of asylum applications and asylum laws (e.g., Hatton, 2004; Thielemann, 2004).

It could be argued, however, that foreign firms are likely to be attracted to regions with high-skilled workers because most such firms that are growing are in high-skill and knowledgebased industries, and thus the number of refugees admitted may not be an appropriate measure for capturing the effects of immigration policy on FDI. Although more and more foreign investors have allocated funding to skill-intensive firms in the U.S., the manufacturing sector has seen the most FDI in the U.S. over the past 20 years (Jackson, 2017). It is also important to note that the measure for FDI used in this research is the aggregate amount of FDI inflow to the U.S., regardless of industry. In the link between immigration policy and FDI, one must consider the potential benefits of a large immigrant population, including both skilled and unskilled immigrants, who would be a critical source of labor and consumption.

Indeed, many studies of FDI suggest that foreign firms are more likely to invest in countries that have a relatively high share of unskilled labor due to lower wages (e.g., Carr et al., 2001; Blonigen and Piger, 2014). Some studies also find that, on average, FDI does not relate to the high-skilled sectors and that even major firms tend to strategically avoid localities with highly skilled workers due to concerns over knowledge leakage (Chung and Alcacer, 2002; Shaver and Flyer, 2000). Also, we wouldn't be able to assert that refugees are a potential source of increasing low-skilled workforces; many of them are high-skilled refugees who can apply their skills productively. Admitted refugees constitute an investment in human capital and their presence has a positive impact, stabilizing existing labor markets in the host country. It is argued that increasing refugee acceptance could reallocate native workers to more productive and demanding sectors, allowing the refugees to take over the low-skilled tasks (Andersson et al., 2019; Ottaviano and Peri, 2012). Thus, this study uses the annual refugee admission ceiling as a percentage of a total population in the U.S. as a primary measure for immigration policy. I expect that larger proportional refugee ceiling is associated with FDI inflows as a percentage of GDP. The data are drawn from Migration Policy Institute. 
To ensure that the results found for the figures for the annual refugee ceiling are not an artifact of data selection, I provide a year dummy for major immigration reform. Each major immigration law contains substantial information on the government's attitude toward immigration. Following suggestions found in existing immigration studies, therefore, I use a binary variable for immigration policy to indicate years in which a government attempts to restrict the number of immigrants (e.g., Karemera et al., 2000; Hatton, 2004). A dummy variable is used to identify the effects of the changes in U.S. immigration policy of 1976, 1980, 1986, 1994, 1996, 2001, 2002, 2004, 2005, and 2006. These indicate the time points when the U.S. government adopted major immigration reform. A summary of each major immigration law is provided in Appendix 1.

In addition to the immigration law variable as an alternative measure of immigration policy, this study also adopts a variable that measures the potential effects of high-skilled immigrants on FDI. Skilled workers could be measured by either the number of H-1B visas issued or the lawful permanent resident population because immigrants in this category are admitted based on quality and merit. This is measured by the number of lawful permanent residents per capita because reliable data for $\mathrm{H}-1 \mathrm{~B}$ visas are only available from 2004, after which point there have been no substantial changes to the $\mathrm{H}-1 \mathrm{~B}$ quotas.

Last, the models include unit labor costs as the mediating variable that explains the indirect effects of immigration policies. I expect that a change in labor costs would negatively affect FDI inflows into the U.S. As discussed earlier, large increases in labor costs will discourage potential firms from making an investment. Thus, I expect that changes in labor cost are negatively associated with FDI inflows. I use labor costs with the index of the unit labor cost of manufacturing in the U.S., which is measured as the cost of labor input required to produce one unit of output. Based on the data from Bureau of Labor Statistics, these data include output, total labor hours, and total compensation. I expect that the year dummy variable indicating immigration restriction is negatively correlated with FDI inflows.

\section{Control Variables}

To control for alternative determinants of FDI, all models include a set of variables including government policies, regulation, and market characteristics. First, it is important to note that both taxes and regulations are particularly important for efficiency-seeking foreign firms (Kandogan, 2012). To control for government direct incentive policy, I include the measure of the top marginal corporate tax rates. Since multinational corporations are sensitive to the existing tax rates, I expect both corporate tax rates and regulation to correlate negatively with FDI. The national corporate tax rates are from Tax Policy Center. The government regulation variable is measured as the total pages in the code of federal regulation. The data is obtained from the Federal Register. In addition to the government regulation, the models include the union membership rate. Previous studies suggest that higher unionization rate decreases FDI not only because it leads to the increased levels of wages, but because it makes managerial control of the production process harder (e.g., Owen, 2013). The union membership rate is measured as the percentage of wage and salary workers who holds the union membership. The data is from Bureau of the Labor Statistics. 
Second, the government expenditure variable is the general government's final consumption expenditure, which includes government consumption of goods and services for current use, as a percentage of GDP. ${ }^{4}$ While most of neoclassical economics and empirical works on economic growth suggest that government consumption expenditure should have a negative relationship with growth, more recent works on new growth theory has stressed the potentially positive role of the government's consumption on macro-economic performance (Barro, 1990; Lucas, 1990). According to Keynesian theory, government spending-particularly an increase in budget deficits-stimulates economic growth by enhancing the purchasing power of individuals. By contrast, some economists suggest that debt-financed increases lead to higher interest rates, which dampens potential investment. Despite this range of perspectives on the impact of government spending, however, there is a growing consensus in empirical studies that government consumption spending, including both non-market goods and individual social goods, has little effect on subsequent economic growth (e.g., Barro, 1990; Connolly and Li, 2016; Hansson and Henrekson, 1994). Thus, I expect a negative correlation between government expenditures and FDI inflows, following the recent findings on this issue.

In addition, the models control for national economic and market conditions. The economic growth variable marks the annual percentage of change in GDP at market prices. Economic growth rates have an effect on domestic markets. Thus, I expect to see a positive impact of market conditions on FDI inflows. Scholars suggest that investors pay closer attention to larger and wealthier countries due to the higher expected returns from them. The variable of market size variable is measured as the log of population, which accounts for market volume and potential. The models also include real interest rate. This is computed as the difference between the prime rate, as charged by banks, and the rate of inflation, as measured by growth in the GDP deflator. Firms are more likely to invest in regions with higher interest rate because they can expect to earn more benefits. Thus, I expect the real interest rate is positively correlated with FDI inflows. The variable for inflation variable reflects an annual percentage for change in the GDP deflator. This is also measured as\% change in the price deflator. Ahlquist (2006, p. 692) argues that "the price deflator measure has marginally better time series coverage and international investors are arguably interested in overall price stability in the economy, not just prices for final consumption goods." Thus, I assume that the inflation variable is negatively associated with FDI inflows. Last, trade openness is measured as imports and exports of goods and services, divided by GDP. Trade is the traditional measure used by studies investigating the effects of economic openness. I expect that trade openness is positively associated with FDI inflows.

\section{Statistical Method}

This study suggests that more expansive immigration policy directly attracts FDI due to the positive effects of immigrant networks. In addition to this direct effect, this paper argues that more expansive immigration policies indirectly lead to increased FDI inflows by putting downward pressure on labor costs. To assess both the direct and indirect effects, I use path

\footnotetext{
${ }^{4}$ All control variables are from the World Bank's World Development Indicator 2017 unless otherwise noted.
} 
analysis of the causal mechanisms among immigration, labor costs, and FDI. Spurious regression problems, including the presence of unit root, the existence of co-integration, and endogeneity, can be expected in a traditional regression analysis of time series data. Therefore, I conduct a set of diagnostic tests.

First, running an augmented Dickey-Fuller (ADF) test, I detect that all variables are nonstationary, except for three: refugee ceiling per capita, economic growth, and market size. The results of the ADF are given in Table 2. Second, I perform the Johnsen co-integration test with co-integrating ranks $(r)$ to see if there is any co-integration between the explanatory and the outcome variables. The results are presented in Table 3 . The adjusted trace statistics indicate that the null hypothesis of no co-integration relationship between variables is rejected, and there exist at least four co-integration relationships between variables at $5 \%$. Therefore, we believe a long-term relationship exists between the variables in the model. The results are reported as follows.

Overall, the results of the diagnostic tests suggest that single equation error-correction models (ECM) are the most appropriate for dealing with the presence of non-stationarity and cointegration in time series data (Beck and Katz, 1996; De Boef and Keele, 2008). The ECM allows us to observe the immediate short-term impact of independent variables using differenced values and their long-term impact using the lagged levels. Naturally, the ECM models remove trends for all variables, including the FDI measure. Intuitively, it would be unrealistic to expect that change in immigration policy would only cause a change in FDI inflows in the following year. Immigrants usually take time to make the decision to migrate when the immigration laws change. Thus, it would take a while to see some substantial effects of immigration reforms, and foreign firms would want to take time to see the results of a policy. Traditional linear regression methods, therefore, cannot capture the possible long-run impacts of a change in immigration policies.

Following the traditional literature on mediation and the merits of the ECM, both direct and indirect effects of immigration policies are estimated, using the following set of linear equations, which model single-level, simple mediation analysis. It is also important to empirically specify the models that examine how the increased labor costs induced by more restrictive immigration policy affect FDI using two estimations. Structural equation models are used to investigate the causal mechanisms for the key independent (immigration policy), mediating (labor costs), and dependent (FDI inflows) variables.

$$
\begin{aligned}
& \Delta F D I_{t}= \\
& \beta_{0}+\beta_{1} \text { FDI }_{t-1}+\beta_{2} \Delta \text { IMMIGRATION }{ }_{t}+\beta_{3} \text { IMMIGRATION }_{t-1}+\beta_{4} \Delta \text { LABOR }_{t}+ \\
& \beta_{4} L A B O R_{t-1}+\beta_{k} \Delta X_{t}+\beta_{k} X_{t-1}+\varepsilon_{t} \ldots \ldots \ldots \ldots \ldots \ldots \ldots \ldots \ldots \ldots \ldots \ldots \ldots \ldots \ldots \ldots \\
& \triangle \text { LABOR }_{t}=\beta_{0}+\beta_{1} \text { LABOR }_{t-1}+\beta_{2} \text { IIMMIGRATION }_{t}+\beta_{3} \text { IMMIGRATION }_{t-1}+
\end{aligned}
$$

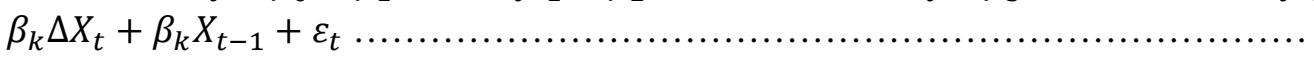

where subscript $t$ denotes time, and $\varepsilon$ denotes a stochastic error term, and $\Delta$ denotes the first difference operator. I model each equation by operating such that the change in the dependent variable from the year $t-1$ to year $t$ is a function of both the differenced and lagged major 
Table 2: The Results of Dickey-Fuller Unit Root Test

\begin{tabular}{lcc}
\hline Variables & On level series & $\begin{array}{c}\text { On first difference } \\
\text { series }\end{array}$ \\
\hline FDI Inflows & -2.006 & $-7.019^{* * *}$ \\
Refugee ceiling per capita & $-4.882^{* * *}$ & - \\
Labor cost & -2.755 & $-4.559^{* * *}$ \\
Corporate tax & -1.496 & $-4.158^{* * *}$ \\
Regulation & -1.203 & $-6.119^{* * *}$ \\
Government expenditures & -1.994 & $-4.568^{* * *}$ \\
Economic growth & $-4.962^{* * *}$ & - \\
Market size & $-2.813^{* *}$ & - \\
Interest rate & -1.980 & $-6.642^{* * *}$ \\
Inflation & -2.066 & $-5.498^{* * *}$ \\
Trade openness & -1.740 & $-6.863^{* * *}$ \\
Union membership & -2.595 & $-6.571^{* * *}$ \\
\hline
\end{tabular}

Note: Null hypothesis is that each variable contains unit root. The asterisks $* * *$ and $* *$ denote the significance level at $1 \%$ and $5 \%$, respectively.

Table 3: The Results of Johansen Cointegration Test

\begin{tabular}{cccc}
\hline $\begin{array}{c}\text { Null } \\
\text { Hypothesis }\end{array}$ & Alternative Hypothesis & Trace Statistics & Max -Eigen Statistics \\
\hline $\mathrm{r}=0$ & $\mathrm{r} \geq 1$ & $293.349^{* * *}$ & $81.159^{* * *}$ \\
$\mathrm{r} \leq 1$ & $\mathrm{r} \geq 2$ & $212.190^{* * *}$ & $64.156^{* * *}$ \\
$\mathrm{r} \leq 2$ & $\mathrm{r} \geq 3$ & $148.034^{* * *}$ & $46.222^{* *}$ \\
$\mathrm{r} \leq 3$ & $\mathrm{r} \geq 4$ & $101.812^{* *}$ & $43.242^{* *}$ \\
$\mathrm{r} \leq 4$ & $\mathrm{r} \geq 5$ & 58.571 & 24.877 \\
$\mathrm{r} \leq 5$ & $\mathrm{r} \geq 6$ & 33.394 & 18.223 \\
$\mathrm{r} \leq 6$ & $\mathrm{r} \geq 7$ & 15.471 & 10.478 \\
$\mathrm{r} \leq 7$ & $\mathrm{r} \geq 8$ & 4.993 & 4.920 \\
$\mathrm{r} \leq 8$ & $\mathrm{r} \geq 9$ & 0.073 & 0.073 \\
\hline
\end{tabular}

Note: The asterisks *** and $* *$ denote the significance level at $1 \%$ and $5 \%$, respectively. 
independent variables with the lagged dependent variable. $\Delta X_{t}$ denotes the set of the differenced control variables, and $\Delta X_{t-1}$ represents their lagged values. Equation (1) estimates the direct effects of immigration policies on FDI inflows with the mediating variable-labor costsincluded as the predictor in the model. Equation (2) estimates the indirect effects of immigration policies on FDI inflows, using the mediating variable from equation (1) as the dependent variable. These equations describe labor costs and FDI inflows as endogenous factors determined by an exogenous variable, immigration policy. ${ }^{5}$ Ordinarily, structural equation models are limited to situations where linear regression models are appropriate for both mediator and outcome (Keele, 2015). Thus, I include control variables to explain both mediating variable (unit labor cost) and outcome variable (FDI) in the models. While variables for differenced FDI and labor cost should ameliorate the endogeneity problem, it is important to ensure that at least a weak exogeneity exists in the models. To detect the presence of endogeneity, I perform Granger causality tests. The results show that the null hypotheses that FDI does not Granger-cause immigration policy, and that FDI does not Granger-cause labor costs cannot be rejected.

\section{Empirical Results}

Table 4 shows the results of the estimations of ECM that investigate the direct impact of national immigration policies on FDI inflows in the U.S. The overall results support the Hypothesis 1, that more expansive immigration policies attract more FDI. First, to get some sense of the robustness of the results, I estimate alternative specifications by including only the lagged dependent variables and the differenced and lagged values of the primary independent variables, without the control variables. The results from the alternative specifications in Column 1 indicate that the impact of immigration policy, measured in terms of annual refugee admissions per capita, on FDI inflows is positively and statistically significant at the 0.05 level, but only in its short-term effect. As shown in Column 3, the variable of restrictive immigration law, an alternative measure of immigration policy, is negatively and significantly correlated with FDI inflows in both the short and long term. Column 5 shows that the coefficient value of the lawful permanent resident variable is positively correlated with FDI, suggesting that higher numbers of lawful permanent residents increase FDI. Its impact, however, is only distinguishable in the short term. The mediating variable, unit labor costs, is negatively and significantly associated with FDI in all models.

\footnotetext{
5 Although the two equations provide robust empirical tests, I conducted preliminary mediation model tests using AMOS Version 26.0 to explore whether the immigration policy-FDI relationship could be explained with labor costs. As shown in Figure A1 in Appendix 2, the refugee ceiling per capita is positively and significantly $(\beta=15.38, \mathrm{P}=$ $0.05)$ correlated with FDI inflows; higher refugee ceiling per capita predicts lower labor costs $(\beta=-133.77, \mathrm{P}=$ $0.10)$, which in turn, predict more FDI inflows $(\beta=-0.03, \mathrm{P}=0.05)$. As shown in Figure 2 , the alternative measure of immigration policy, restrictive immigration law, is negatively and significantly $(\beta=-0.12, \mathrm{P}=0.10)$ associated with FDI; more restrictive immigration law predicts higher labor costs $(\beta=6.17, \mathrm{P}=0.10)$, which in turn, predict less FDI inflows $(\beta=-0.02, P=0.05)$. Overall, liberal immigration policies directly increase FDI inflows and decrease labor costs.
} 
Table 4. The Impact of Immigration Policy on FDI Inflows in the U.S.

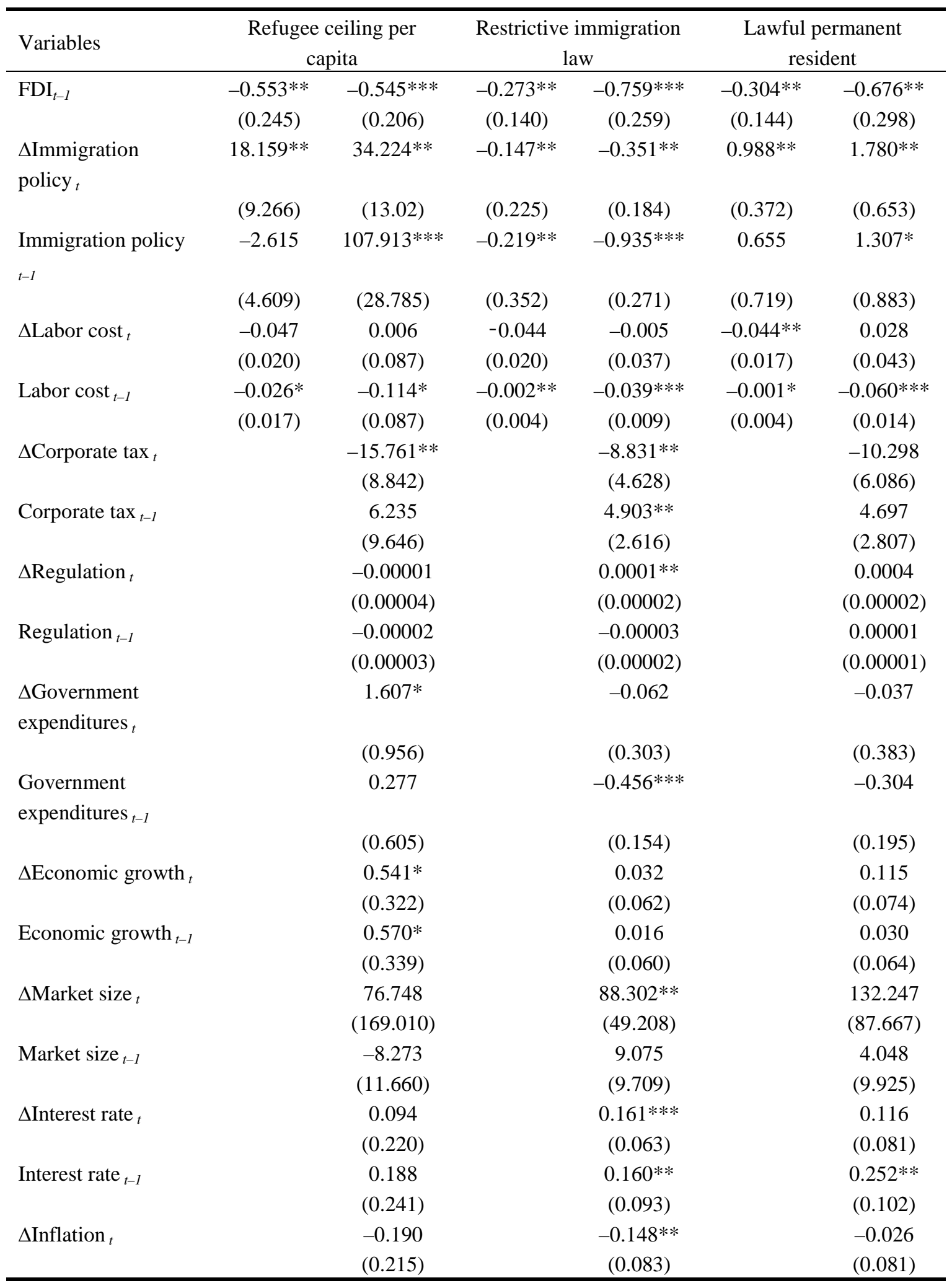




\begin{tabular}{|c|c|c|c|c|c|c|}
\hline Inflation $_{t-1}$ & & $\begin{array}{c}-0.507^{*} \\
(0.297)\end{array}$ & & $\begin{array}{c}0.045 \\
(0.079)\end{array}$ & & $\begin{array}{c}0.010 \\
(0.102)\end{array}$ \\
\hline$\Delta$ Trade openness ${ }_{t}$ & & $\begin{array}{l}-0.052 \\
(0.176)\end{array}$ & & $\begin{array}{c}0.178^{* *} \\
(0.101)\end{array}$ & & $\begin{array}{c}0.040 \\
(0.131)\end{array}$ \\
\hline Trade openness $_{t-1}$ & & $\begin{array}{c}0.022 \\
(0.142)\end{array}$ & & $\begin{array}{c}-0.137 * * \\
(0.080)\end{array}$ & & $\begin{array}{l}-0.107 \\
(0.117)\end{array}$ \\
\hline$\Delta$ Union membership $_{t}$ & & $\begin{array}{l}-0.514 \\
(0.534)\end{array}$ & & $\begin{array}{l}-0.059 \\
(0.146)\end{array}$ & & $\begin{array}{l}-0.088 \\
(0.103)\end{array}$ \\
\hline Union membership $_{t-1}$ & & $\begin{array}{c}-0.946^{*} \\
(0.649)\end{array}$ & & $\begin{array}{c}-0.149^{* * *} \\
(0.044)\end{array}$ & & $\begin{array}{c}-0.158^{* *} \\
(0.060)\end{array}$ \\
\hline Constant & & $\begin{array}{c}178.046 \\
(227.875)\end{array}$ & & $\begin{array}{l}-162.086 \\
(185.431)\end{array}$ & $\begin{array}{c}0.335 \\
(0.368)\end{array}$ & $\begin{array}{c}-69.133 \\
(191.851)\end{array}$ \\
\hline R-Squared & 0.538 & 0.929 & 0.515 & 0.831 & 0.505 & 0.774 \\
\hline Durbin-Watson & 1.766 & 2.811 & 1.873 & 2.488 & 1.793 & 2.197 \\
\hline
\end{tabular}

Note: Prais-Winsten (PW) estimation is used here. ${ }^{*} p<.10,{ }^{* *} p<.05,{ }^{* * *} p<.01$; one-tailed test. Semirobust standard errors are in parenthesis.

Next, Columns 2, 4, and 6 report the result estimations testing the impact of immigration policy on FDI inflows, with all control variables. As shown in Column 2, the coefficient estimates of the differenced value of annual refugee admission per capita are positively and statistically significant at the 0.05 level in the short term. This indicates that, holding all else equal, where the annual refugee ceiling per total population increases 1\%, the FDI growth rate increases by $34.2 \%$. The lagged measure of the annual refugee ceiling in relation to total population, which indicates the long-term relationship to FDI, is also positive and significant at the 0.01 level. The actual magnitude, the so-called long-term multiplier, suggests that the growth rate for FDI will continue to change a total of $196 \%$ following a one $\%$ increase in the annual refugee ceiling. The error correction rate $(-0.55)$ indicates that FDI growth rate will change $107.8 \%$ after one year, another $59.3 \%$ after two years, $32.6 \%$ after three years, and so on, until the two series come back to equilibrium. These results suggest that when it has more expansive immigration law, the U.S. will receive more FDI. Column 4 shows the results of the alternative model, which tests the impact of reforms of U.S. immigration law on FDI inflows. The coefficient of the differenced term of immigration laws is negative and significant, suggesting that an immigration restriction leads to an immediate $0.4 \%$ decrease in FDI growth rate. Furthermore, the coefficient for the lagged level is also negative and statistically significant at the 0.01 level. This suggests that immigration restrictions lead to a $1.2 \%$ decrease in predicted FDI growth rate over the long term. Additionally, Column 6 reports that both the differenced and lagged terms of the lawful permanent resident variable are positively and statistically significantly associated with FDI. The results suggest in particular that lawful permanent residents leads to a $1.9 \%$ increase in predicted FDI growth rate over the long term. Although the three measures of immigration policies show significantly different impacts on FDI growth rate, together they indicate a strong positive impact of expansive immigration policies on FDI.

As expected, Columns 2, 4, and 6 show that the mediating variable, unit labor costs, is negative and statistically significant (at the 0.10 , the 0.01 , and the 0.01 levels, respectively) 
particularly over the long term. In the ECM model, which includes the annual refugee ceiling, a $1 \%$ increase in unit labor costs leads to a $0.2 \%$ decrease in predicted FDI growth rate over the long term. Further, in the long-term expectation, a $1 \%$ increase in unit labor costs causes a $0.05 \%$ in FDI growth rate in the model that includes years of restrictive immigration laws, and a $0.09 \%$ decrease in FDI growth rate in the model that includes the number of lawful permanent residents per capita. The results indicate a strong negative relationship between labor costs and FDI, particularly over the long run.

For the other key control variables, the results from both models shown in Table 4 indicate that most of the control variables perform largely as expected. The coefficients for the corporate tax variable are negative and statistically significant in the short term. The empirical results for the impact of government expenditure on FDI show different results for the different measures of immigration policy. Both the differenced and lagged values in the model that measures immigration policy as annual refugee admission ceiling per capita are positively associated with FDI inflows, but the effect is only marginally significant with the differenced value. However, the coefficients for government consumption expenditure variables are negatively correlated with FDI inflows in the model that measures immigration policy with immigration law, but only the effect of the lagged value of expenditure on FDI is statistically significant. ${ }^{6}$ As expected, the economic growth variable is positive and significant both in the short- and long-term expectations. The inflation rate is negative and significant only over the long term. However, these three variables are only statistically significantly different in the ECM model that includes the annual refugee ceiling per capita. Last, the coefficients for union membership indicate a negative and statistically significant long-run effect on FDI growth rate. These results indicate that high unionization may signal a less friendly business climate.

As alternative specifications of the models that omit control variables, Table 5 reports findings from ECMs that investigate the link between immigration policies and the mediating variable of labor costs. The results from Columns 1 and 3 indicate that liberal immigration policies increase FDI inflows, suggesting that the refugee ceiling and the restrictive immigration law variables are negatively and positively correlated, respectively, with unit labor costs, particularly for long-run expectations. These results are all statistically significant at the 0.05 level. Additionally, the results from Column 5 indicate that the lagged measure for lawful permanent resident is negatively and significantly associated with unit labor costs. The results from the full models with all control variables (Columns 2, 4, and 6) are substantively unchanged: the lagged values for all three indicators of the federal immigration policy are statistically significantly correlated with unit labor costs. Specifically, Column 2 indicates that unit labor costs change by a total of $196 \%$ following a $1 \%$ increase in the annual refugee admission ceiling per population. The results from Columns 4 and 6 indicate that a year of restrictive immigration reform and a $1 \%$ increase in lawful permanent resident per capita will lead to a $13.4 \%$ increase and a $26.9 \%$ decrease in unit labor costs, respectively, over the long

\footnotetext{
6 Although different indicators of government consumption spending could be produced in relation to the different measures of immigration policy, the empirical results in this research suggest that while the impact of government consumption spending acts to support foreign investment in the short run, it gradually decreases economic performance and thereby decreases potential investment from foreign firms over the long run. These findings basically align with those elsewhere on the negative link between government consumption spending and growth.
} 
term. These results indicate that more liberal immigration policies can be expected to significantly reduce unit labor costs.

Table 5: The Impact of Immigration Policy on Labor Costs in the U.S.

\begin{tabular}{|c|c|c|c|c|c|c|}
\hline \multirow{2}{*}{$\begin{array}{l}\text { Variables } \\
\text { Labor cost }_{t-1}\end{array}$} & \multicolumn{2}{|c|}{ Refugee ceiling per capita } & \multicolumn{2}{|c|}{$\begin{array}{c}\text { Restrictive immigration } \\
\text { law }\end{array}$} & \multicolumn{2}{|c|}{$\begin{array}{c}\text { Lawful permanent } \\
\text { resident }\end{array}$} \\
\hline & $\begin{array}{l}-0.127^{* * *} \\
(0.052)\end{array}$ & $\begin{array}{c}-0.536 * * * \\
(0.140)\end{array}$ & $\begin{array}{c}-0.079 * * \\
(0.037)\end{array}$ & $\begin{array}{c}-0.105^{* *} \\
(0.059)\end{array}$ & $\begin{array}{c}-0.101^{* *} \\
(0.042)\end{array}$ & $\begin{array}{l}-0.125^{*} \\
(0.067)\end{array}$ \\
\hline $\begin{array}{l}\Delta \text { Immigration } \\
\text { policy }_{t}\end{array}$ & $\begin{array}{l}134.797 \\
(79.708)\end{array}$ & $\begin{array}{c}81.100 \\
(60.722)\end{array}$ & $\begin{array}{l}-0.470 \\
(1.391)\end{array}$ & $\begin{array}{l}-0.709 \\
(0.873)\end{array}$ & $\begin{array}{r}4.588 \\
(5.408)\end{array}$ & $\begin{array}{l}-6.280 * \\
(3.237)\end{array}$ \\
\hline Immigration policy $y_{t-1}$ & $\begin{array}{c}- \\
122.425^{* *} \\
(42.627)\end{array}$ & $\begin{array}{c}-139.450^{* *} \\
(77.176)\end{array}$ & $\begin{array}{l}2.209 * * \\
(1.779)\end{array}$ & $\begin{array}{l}1.411^{* *} \\
(0.809)\end{array}$ & $\begin{array}{c}-4.330 * \\
(6.020)\end{array}$ & $\begin{array}{l}-3.361^{*} \\
(4.330)\end{array}$ \\
\hline$\Delta$ Corporate tax $t_{t}$ & & $\begin{array}{l}38.964^{*} \\
(24.047)\end{array}$ & & $\begin{array}{c}23.407^{* *} \\
(12.325)\end{array}$ & & $\begin{array}{c}22.278 * * \\
(10.759)\end{array}$ \\
\hline Corporate tax $\mathrm{t}_{t-1}$ & & $\begin{array}{c}-47.676^{* * *} \\
(16.911)\end{array}$ & & $\begin{array}{c}1.383 \\
(8.976)\end{array}$ & & $\begin{array}{c}-14.099 \\
(8.599)\end{array}$ \\
\hline$\Delta$ Regulation $_{t}$ & & $\begin{array}{l}0.0002 * * \\
(0.0001)\end{array}$ & & $\begin{array}{l}0.0002 * \\
(0.0001)\end{array}$ & & $\begin{array}{l}0.0002^{*} \\
(0.0001)\end{array}$ \\
\hline Regulation $_{t-1}$ & & $\begin{array}{l}7.67 \mathrm{e}-06 \\
(0.0001)\end{array}$ & & $\begin{array}{c}0.0002^{* * *} \\
(0.0001)\end{array}$ & & $\begin{array}{l}0.0002 * * \\
(0.0001)\end{array}$ \\
\hline $\begin{array}{l}\Delta \text { Government } \\
\text { expenditures }_{t}\end{array}$ & & $\begin{array}{l}-4.017^{*} \\
(2.620)\end{array}$ & & $\begin{array}{l}2.214^{*} \\
(1.364)\end{array}$ & & $\begin{array}{l}2.588^{*} \\
(1.314)\end{array}$ \\
\hline $\begin{array}{l}\text { Government } \\
\text { expenditures }_{t-1}\end{array}$ & & $\begin{array}{c}-4.414^{* * *} \\
(1.132)\end{array}$ & & $\begin{array}{c}-1.161^{* *} \\
(0.648)\end{array}$ & & $\begin{array}{l}-1.205^{*} \\
(0.669)\end{array}$ \\
\hline$\Delta$ Economic growth $_{t}$ & & $\begin{array}{c}-2.095^{* * *} \\
(0.761)\end{array}$ & & $\begin{array}{l}-0.161 \\
(0.265)\end{array}$ & & $\begin{array}{l}-0.037 \\
(0.261)\end{array}$ \\
\hline 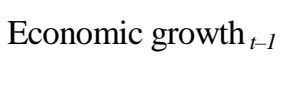 & & $\begin{array}{c}-1.815^{* *} \\
(0.917)\end{array}$ & & $\begin{array}{c}0.345 \\
(0.309)\end{array}$ & & $\begin{array}{c}0.478 \\
(0.306)\end{array}$ \\
\hline$\Delta$ Market size $_{t}$ & & $\begin{array}{c}1146.537 * * * \\
(326.771)\end{array}$ & & $\begin{array}{c}205.278 \\
(285.112)\end{array}$ & & $\begin{array}{l}-136.126 \\
(314.958)\end{array}$ \\
\hline Market size $_{t-1}$ & & $\begin{array}{c}-38.269 * \\
(27.327)\end{array}$ & & $\begin{array}{c}-95.973 * * * \\
(26.975)\end{array}$ & & $\begin{array}{c}-111.625^{* * *} \\
(26.645)\end{array}$ \\
\hline$\Delta$ Interest rate $_{t}$ & & $\begin{array}{c}-1.592 * * * \\
(0.335)\end{array}$ & & $\begin{array}{l}-0.454 \\
(0.374)\end{array}$ & & $\begin{array}{l}-0.481 \\
(0.359)\end{array}$ \\
\hline Interest rate $_{t-1}$ & & $\begin{array}{c}-1.161^{* * *} \\
(0.353)\end{array}$ & & $\begin{array}{l}-0.342 \\
(0.330)\end{array}$ & & $\begin{array}{l}-0.216 \\
(0.301)\end{array}$ \\
\hline$\Delta$ Inflation $_{t}$ & & $\begin{array}{l}-0.883^{*} \\
(0.515)\end{array}$ & & $\begin{array}{l}-0.054 \\
(0.382)\end{array}$ & & $\begin{array}{l}-0.002 \\
(0.342)\end{array}$ \\
\hline Inflation $_{t-1}$ & & $-1.233^{* *}$ & & 0.202 & & 0.050 \\
\hline
\end{tabular}




\begin{tabular}{|c|c|c|c|c|c|c|}
\hline & & $(0.503)$ & & $(0.338)$ & & $(0.307)$ \\
\hline$\Delta$ Trade openness $_{t}$ & & $\begin{array}{c}0.938 * * \\
(0.396)\end{array}$ & & $\begin{array}{c}0.296 \\
(0.473)\end{array}$ & & $\begin{array}{c}0.284 \\
(0.425)\end{array}$ \\
\hline Trade openness $_{t-1}$ & & $\begin{array}{c}0.831 * * * \\
(0.232)\end{array}$ & & $\begin{array}{c}0.816^{* * *} \\
(0.327)\end{array}$ & & $\begin{array}{c}1.105^{* * *} \\
(0.362)\end{array}$ \\
\hline$\Delta$ Union membership $_{t}$ & & $\begin{array}{l}-0.562 \\
(1.428)\end{array}$ & & $\begin{array}{c}-0.805^{*} \\
(0.610)\end{array}$ & & $\begin{array}{l}-0.838 \\
(0.570)\end{array}$ \\
\hline Union membership $t-1$ & & $\begin{array}{c}3.884^{* * *} \\
(1.312)\end{array}$ & & $\begin{array}{l}-0.416 \\
(0.321)\end{array}$ & & $\begin{array}{l}-0.256 \\
(0.442)\end{array}$ \\
\hline Constant & $\begin{array}{l}8.267^{* *} \\
(4.359)\end{array}$ & $\begin{array}{l}809.675 * \\
\text { (522.687) }\end{array}$ & $\begin{array}{c}8.442 * * * \\
(3.434)\end{array}$ & $\begin{array}{c}1850.829 * * * \\
(520.054)\end{array}$ & $\begin{array}{l}8.582^{* *} \\
(3.421)\end{array}$ & $\begin{array}{c}2155.373^{* * *} \\
(514.702)\end{array}$ \\
\hline R-Squared & 0.535 & 0.975 & 0.555 & 0.952 & 0.528 & 0.961 \\
\hline Durbin-Watson & 2.212 & 2.858 & 2.000 & 3.030 & 2.047 & 3.117 \\
\hline
\end{tabular}

Note: Prais-Winsten (PW) estimation is used here. ${ }^{*} p<.10,{ }^{* *} p<.05$, ${ }^{* * *} p<.01$; one-tailed test. Semirobust standard errors are in parenthesis.

Five control variables, namely, the differenced corporate tax, regulation, lagged government expenditure, market size, and trade openness, are statistically significant in two models. The differenced corporate tax variable is positively correlated with labor costs, suggesting that higher corporate tax rates and regulations decrease businesses and industrial activities, which in turn increase labor costs. As expected, the estimated long-term coefficient for government expenditures is negatively and significantly correlated to labor costs. This suggests that increased government expenditures are transferred to increase economic resources, which lower labor costs. ${ }^{7}$ Additionally, market size measured as logged population is negatively associated with labor costs. It is important to note that market size is operationalized as market volume and potential, which can be measured as population growth (e.g., Campbell and Hopenhayn, 2005). Indeed, labor market responses to population growth, and thus a larger population would increase labor supply, thereby decreasing labor costs (e.g., Bloom and Freeman, 1986; Jorgenson et al., 2008). Last, the long-term positive effects of trade openness on labor costs suggest that trade openness increases labor costs by raising employee incomes, resulting in increasing consumption. ${ }^{8}$

\footnotetext{
7 Both neoclassical and New Keynesian models indicate that an increase in government consumption spending accompanies the increase of tax financing, which in turn induces a negative wealth effect by not only reducing net household wealth but also increasing labor supply. It leads to a fall in labor costs as well as real wages (e.g., Angeletos and Panousi, 2009; Barro, 1981; Baxter and King, 1993).

8 Structural changes in the labor market after trade liberalization not only decreases fixed costs of production but also increases the productivity of goods, which leads to increased wage premiums for skilled labor relative to unskilled labor due to the increase in profits (Arbache et al., 2004; Comite et al., 2018). Many studies have also shown that a reduction in trade barriers increases the relative demand for skilled labor by reallocating factors toward more skillintensive firms (Burstein and Vogel, 2017; Feenstra and Hanson, 1997).
} 


\section{$5 \quad$ Conclusions and Discussion}

Many studies on FDI explore the association between economic and political incentives and foreign firms' location decisions. Major potential determinants are noted, including some costrelated factors, such as labor costs, financial incentives, including exchange rates, macroeconomic factors, including the size of the current and potential markets, wealth levels, and trade liberalization (e.g., Kandogan, 2012). However, little evidence is available as to which political and/or economic rewards can effectively attract more FDI. Firms can be expected to be rational actors that seek to maximize profits when benefits from all deliberated determinants do not exceed costs. As a result, there is no single acknowledged most important determinant that would influence location decisions by foreign firms. I suggest that another factor is overlooked, namely, immigration policy. The results of this study show an indirect effect of immigration policies, such that more expansive national immigration policies will attract more FDI by lowering labor costs. The findings have significant implications for the study of immigration policy and economic growth. First, the results strongly support the assertion expansive immigration policy forms a window of opportunity for foreign firms to invest or to expand their existing plants. This is particularly true for foreign manufacturing firms, as a liberal immigration policy can lower unit labor costs. Second, it is found that national policymakers can directly increase FDI in manufacturing by manipulating immigration policy and thereby improving the national economic condition. These findings suggest that national-level immigration reforms that have increased legal immigrants have stabilized the labor market and attracted more foreign firms. Thus, a liberal immigration policy is an important determinant for foreign firms that may wish to increase their capital in the U.S.

Despite these potentially significant implications, this article has some limitations. First, the single measures adopted for immigration policy may produce misleading results, as immigration seems to be influenced by actions on multiple policy levels (e.g., Nicholson-Crotty and Nicholson-Crotty, 2011). In the future, research must develop more concrete measures of immigration policy climate insofar as it affects migrant flows. Second, data from the current era of devolution may lead to different findings. Because the increased discretionary authority devolved to state governments may increase the opposition to federal immigration policy and allow them to develop and implement their own immigration policies in response to the preferences of their citizens, foreign firms may no longer make their investment decision based solely on the consequence of federal immigration policy. As a result, the positive impact of immigration policy on FDI inflows would be conditional on the interactions of federal and state governments. For FDI in the U.S., it is important to examine how the policy levers available to state governments can make a particular state more attractive to foreign firms.

Despite the limitations of this study, the findings have potentially significant implications for immigration policy. Countries have sought to attract FDI not only because it adds to their economic resources and capital formation, but also because it can transfer high-production technology and skills, innovative performance, and novel organizational and managerial practices from home countries to host countries. If the U.S. were to adopt a more liberal immigration policy, it would benefit from the potential increase of FDI in a way that could lower potential labor costs and secure a stable supply of labor. 
Acknowledgements This work was supported by the Ministry of Education of the Republic of Korea and the National Research Foundation of Korea (NRF-2018S1A3A2075531).

\section{References}

Ahlquist, J. S. (2006). Economic policy, institutions, and capital flows: Portfolio and direct investment flows in developing countries. International Studies Quarterly, 50, 681-704.

https://www.google.com/search?client=firefox-b-

$\mathrm{d} \& \mathrm{q}=$ Ahlquist\%2C+J.+S.+\%282006\%29.+Economic+policy\%2C+institutions\%2C+and+capital $+\mathrm{f}$ lows\%3A+Portfolio+and+direct+investment+flows+in+developing+countries.+International+Stud ies+Quarterly $\% 2 \mathrm{C}+50 \% 2 \mathrm{C}+681 \% \mathrm{E} 2 \% 80 \% 93704$.

Ali, S., and Guo, W. (2005). Determinants of FDI in China. Journal of Global Business and Technology, $1,21-33$.

https://www.researchgate.net/publication/252703493_Determinants_of_FDI_in_China/link/5562d 29008ae9963a11b4f48/download

Ancharaz, V. D. (2003). The determinants of foreign direct investment in a comparative perspective: Is there a bias against sub-saharan Africa? Working paper in the University of Mauritius Research Journal. Retrieved from http://www.uvm.edu/ wgibson/PDF\%20Library/FDIinSSA.pdf.

Andersson, L. F., Eriksson, R., and Scocco, S. (2019). Refugee immigration and the growth of low-wage work in the EU 15. Comparative Migration Studies, 7(39), 1-19.

http://umu.diva-portal.org/smash/record.jsf?language=sv\&pid=diva2\%3A1350444\&dswid=3637

Angeletos, G. M. and Panousi, V. (2009). Revisiting the supply side effects of government spending. Journal of Monetary Economics, 56(2): 137-153.

https://ideas.repec.org/a/eee/moneco/v56y2009i2p137-153.html

Arbache, J. S., Dickerson, A., and Green, F. (2004). Trade liberalization and wages in developing countries. The Economic Journal, 114(493): F73-F96.

https://academic.oup.com/ej/article/114/493/F73/5089315

Arpan, J. (1981). Motives of non-American firms investing in the United States. Journal of International Business Studies, 12: 25-34.

https://www.jstor.org/stable/154509?seq=1\#metadata_info_tab_contents

Baker, M., and Benjamin, D. (1997). The role of the family in immigrants' labor-market activity: An evaluation of alternative explanations. American Economic Review, 87, 705-727. https://www.jstor.org/stable/2951370?seq=1\#metadata_info_tab_contents

Baldwin, R., and Venables. A. J. (1994). International migration, capital mobility and transitional dynamics. Economica, 61: 285-300.

Barro, R. J. (1981). Output effects of government purchases. Journal of Political Economy, 89(6): 1086-1121.

https://econpapers.repec.org/article/ucpjpolec/v_3a89_3ay_3a1981_3ai_3a6_3ap_3a1086-

1121.htm 
Barro, R. J. (1990) Government spending in a simple model of endogenous growth. Journal of Political Economy, 98, 103-126. https://dash.harvard.edu/handle/1/3451296

Baxter, M., and King, R. G. (1993). Fiscal policy in general equilibrium. American Economic Review, 83(3): 315-334.

https://econpapers.repec.org/article/aeaaecrev/v_3a83_3ay_3a1993_3ai_3a3_3ap_3a315-34.htm

Beck, N., and Katz, J. N. (1996). Nuisance vs. substance: Specifying and estimating time-series-crosssection models. Political Analysis, 6(1): 1-36.

https://www.cambridge.org/core/journals/political-analysis/article/nuisance-vs-substance-

specifying-and-estimating-timeseriescrosssection-

models/AA4839FA8B3FB14F048E10E6E6C858F2

Bernard, A. B., and Moxnes, A. (2018). Networks and trade. Annual Review of Economics, 10, $65-85$. https://www.annualreviews.org/doi/full/10.1146/annurev-economics-080217-053506

Blonigen, B. A., and Piger, J. (2014). Determinants of foreign direct investment. Canadian Journal of Economics, 47(3), 775-812.

https://onlinelibrary.wiley.com/doi/abs/10.1111/caje.12091

Bloom, D. E., and Freeman, R. B. (1986). The effects of rapid population growth on labor supply and employment in developing countries. Population and Development Review, 12(3): 381-414. https://www.jstor.org/stable/1973216?seq=1\#metadata_info_tab_contents

Borjas, G. J. (1999). Heaven's door: Immigration policy and the American economy. Princeton, NJ: Princeton University Press.

https://press.princeton.edu/books/paperback/9780691088969/heavens-door

Burstein, A., and Vogel, J. (2017). International trade, technology, and the skill premium. Journal of Political Economy, 125(5): 1356-1412.

https://econpapers.repec.org/article/ucpjpolec/doi_3a10.1086_2f693373.htm

Campbell, J. R., and Hopenhayn, H. A. (2005). Market size maters. Journal of Industrial Economics, 53(1): 1-25. https://econpapers.repec.org/article/blajindec/v_3a53_3ay_3a2005_3ai_3a1_3ap_3a1-25.htm

Carr, D., Markusen, J. R., and Maskus, K. E. (2001). Estimating the knowledge-capital model of the multinational enterprise. American Economic Review, 91, 603-708. https://www.aeaweb.org/articles?id=10.1257/aer.91.3.693

Chan, S. (1995). Foreign direct investment in a changing global political economy. New York: St. Martin's Press.

Chung, W., and Alcacer, J. (2002). Knowledge seeking and location choice of foreign direct investment in the United States. Management Science, 48, 1534-1554.

https://econpapers.repec.org/article/inmormnsc/v_3a48_3ay_3a2002_3ai_3a12_3ap_3a15341554.htm

Combes, P. P., Lafourcade, M., and Mayer, T. (2005). The trade-creating effects of business and social networks: evidence from France. Journal of International Economics, 66(1), 1-29.

https://econpapers.repec.org/article/eeeinecon/v_3a66_3ay_3a2005_3ai_3a1_3ap_3a1-29.htm 
Comite, F. D., Nocco, A., and Orefice, G. (2018). Trade liberalization and the wage gap: the role of vertical linkages and fixed costs. Review of World Economics, 154(1): 75-115. https://ideas.repec.org/a/spr/weltar/v154y2018i1d10.1007_s10290-017-0293-1.html

Connolly, M., and Li, C. (2016). Government spending and economic growth in the OECD countries. Journal of Economic Policy Reform, 19(4): 386-395.

https://www.tandfonline.com/doi/abs/10.1080/17487870.2016.1213168?journalCode=gpre20

Council of Economic Advisers. (2016). The long-term decline in prime-age male labor force participation. Report.

De Boef, S., and Keele, L. (2008). Taking time seriously. American Journal of Political Science, 52(1): 184-200.

https://onlinelibrary.wiley.com/doi/abs/10.1111/j.1540-5907.2007.00307.x

Feenstra, R. C., and Hanson, G. H. (1997). Foreign direct investments and relative wages: Evidence from Mexico's maquiladoras. Journal of International Economics, 42(3-4): 371-394.

https://econpapers.repec.org/article/eeeinecon/v_3a42_3ay_3a1997_3ai_3a3-4_3ap_3a371393.htm

Foad, H. (2012). FDI and immigration: a regional analysis. The Annals of Regional Science, 49(1), 237-259. https://econpapers.repec.org/article/spranresc/v_3a49_3ay_3a2012_3ai_3a1_3ap_3a237-259.htm

Fry, E. L. (1983). The politics of international investment. New York, NY: McGraw-Hill Book Company.

Gao, T. (2000). Ethnic Chinese networks and international investment evidence from inward FDI in China. University of Missouri, Working Paper.

Gaston, N., and Nelson, D. (2002). Integration, foreign direct investment and labor markets: Microeconomic perspectives. The Manchester School, 70, 420-459. https://onlinelibrary.wiley.com/doi/abs/10.1111/1467-9957.00310

Gheasi, M., and Nijkamp, P. (2017). A brief overview of international migration motives and impact, with specific reference to FDI. Economies, 5(31), 1-11.

https://ideas.repec.org/a/gam/jecomi/v5y2017i3p31-d109008.html

Gould, D. (1994). Immigration links to the home country: Empirical implications for U.S. bilateral trade flows. Review of Economics and Statistics, 76: 302-316.

https://econpapers.repec.org/article/tprrestat/v_3a76_3ay_3a1994_3ai_3a2_3ap_3a302-16.htm

Hansson, P., and Henrekson, M. (1994). A new framework for testing the effect of government spending on growth and productivity. Public Choice, 81(3-4): 381-401.

https://link.springer.com/article/10.1007/BF01053239

Hatton, T. J. (2004). Seeking asylum in Europe. Economic Policy, 19, 5-62. https://www.jstor.org/stable/1344715?seq=1\#metadata_info_tab_contents

Ivlevs, A. (2006). Migration and foreign direct investment in the globalization context: the case of a small open economy. Development Working Paper from Centro Studi Luca d'Agliano, University of Milano, available at http://www.dagliano.unimi.it/media/WP2006_209.pdf .

Jackson, J. K. (2017). Foreign direct investment in the United States: An economic analysis. Congressional Research Service Report. 
Javorcik, B. S., Ozden C., Spatareanu M, and Neagu C. (2011). Migrant networks and foreign direct investment. Journal of Development Economics, 94, 231-241.

https://econpapers.repec.org/article/eeedeveco/v_3a94_3ay_3a2011_3ai_3a2_3ap_3a231-241.htm

Jensen, N. M. (2003). Democratic governance and multinational corporations: Political regimes and inflows of foreign direct investment. International Organization, 57(3), 587-616.

https://www.jstor.org/stable/3594838?seq=1\#metadata_info_tab_contents

Jorgenson, D. W, Goettle, R. j., Ho, M. S., Slesnick, D. T., and Wilcoxen, P. J. (2008). U.S. labor supply and demand in the long run. Journal of Policy Modeling, 30(4): 603-618.

Kandogan, Y. (2012). Regional foreign direct investment potential of the states within the US. Journal of Economics and Business, 64, 306-322. https://econpapers.repec.org/article/eeejebusi/v_3a64_3ay_3a2012_3ai_3a4_3ap_3a306-322.htm

Karemera, D., Lwuagwu, V. L., and Davis, B. (2000). A gravity model analysis of international migration to North America. Applied Economics, 32(13): 1745-1755. https://ideas.repec.org/a/taf/applec/v32y2000i13p1745-1755.html

Keele, L. (2015). Causal mediation analysis: warning! Assumptions ahead. American Journal of Evaluation, 36(4), 500-513. https://journals.sagepub.com/doi/10.1177/1098214015594689

Kim, C. U. (2006). Immigration, FDI, and international trade”. University of Oregon Economics Department Working Papers, available at http://economics.uoregon.edu/papers/UO-20063_Kim_Immigration.pdf.

Klein, P., and Ventura, G. J. (2007). TFP differences and the aggregate effects of labor mobility in the long run. The B.E. Journal of Macroeconomics, 7(1), 1-38. https://ideas.repec.org/a/bpj/bejmac/v7y2007i1n10.html

Li, Q. (2009). Democracy, autocracy, and expropriation of foreign direct investment. Comparative Political Studies, 42(8), 1098-1127. https://journals.sagepub.com/doi/10.1177/0010414009331723

Li, Q. and Resnick, A. (2003). Reversal of fortunes: Democratic institutions and foreign direct investment inflows to developing countries. International Organization, 57, 175-211.

https://econpapers.repec.org/article/cupintorg/v_3a57_3ay_3a2003_3ai_3a01_3ap_3a175-

211_5f57.htm

Liu, S. X. (1997). Foreign direct investment and the multinational enterprise: A re-examination using signaling theory. Westport, CT: Praeger Publishers.

https://www.bookdepository.com/Foreign-Direct-Investment-Multinational-Enterprise-Scott-XLiu/9780275954833?ref=grid-view

Lucas, R. E. Jr. (1990). Why doesn't capital flow from rich to poor countries? American Economic Review, 80, 92-96.

https://www.jstor.org/stable/2006549?origin=JSTOR-pdf\&seq=1\#metadata_info_tab_contents

Mayda, A. M. (2010). International migration: a panel data analysis of the determinants of bilateral flows. Journal of Population Economics, 23, 1249-1274.

https://link.springer.com/article/10.1007/s00148-009-0251-x 
Moosa, I. A. (2002). Foreign direct investment: Theory, evidence and practice. NY, New York: Palgrave. https://www.palgrave.com/gp/book/9780333945902

Murat, M., and Pistoresi. B. (2006). Emigrants and immigrants networks in FDI. Working paper in the University of Modena, Italy.

Available at http://papers.ssrn.com/sol3/papers.cfm?abstract id=958283.

Naylor, R., and Santoni, M. (2003). Foreign direct investment and wage bargaining. Journal of International Trade and Economic Development, 12 (1), 1-18.

https://www.tandfonline.com/doi/abs/10.1080/0963819032000049178

Nicholson-Crotty, J., and Nicholson-Crotty, S. (2011). Industry strength and immigrant policy in the American states. Political Research Quarterly, 64, 612-624.

https://journals.sagepub.com/doi/10.1177/1065912910373551

Ortega, F., and Peri, G. (2009). The causes and effects of international migrations: Evidence from OECD countries 1980-2005, NBER Working Paper No. 14833, Cambridge, MA. https://www.nber.org/papers/w14833

Ottaviano, G., and Peri, G. (2012). Rethinking the effect of immigration on wages. Journal of the European Economic Association, 10(1), 152-197. https://onlinelibrary.wiley.com/doi/full/10.1111/j.1542-4774.2011.01052.x

Owen, E. (2013). Unionization and restrictions on foreign direct investment. International Interactions, 39, 723-747. https://www.tandfonline.com/doi/abs/10.1080/03050629.2013.834258

Plaut, T., and Pluta. J. (1983). Business climate, taxes and expenditures, and state industrial growth in the United States. Southern Economic Journal, 50, 99-119.

Preston, J., and Bajaj, V. (2011). Indian company under scrutiny over U.S. visas, The New York Times, published June 21, 2011, available at https://www.nytimes.com/2011/06/22/us/22infosys.html, accessed May 1, 2020.

Rauch, J. E., and Trindade, V. (2002). Ethnic Chinese networks in international trade. Review of Economics and Statistics, 84(1), 116-130.

https://www.jstor.org/stable/3211742?origin=JSTOR-pdf\&seq=1\#metadata_info_tab_contents

Rodriguez, C. M. (2010). Constraint through delegation: the case of executive control over immigration policy. Duke Law Journal, 59(8), 1787-1846.

https://scholarship.law.duke.edu/dlj/vol59/iss8/5/

Shaver, J. M., and Flyer, F. (2000). Agglomeration economies, firm heterogeneity, and foreign direct investment in the United States. Strategic Management Journal, 21, 1175-1193.

https://www.jstor.org/stable/3094452?seq=1\#metadata_info_tab_contents

Shin, G. (2018). Corporate tax policy and multinational corporations in the American states: Exploring the intervening effect of local fiscal decentralization. Journal of Urban Affairs, 40(5), 679-704. https://www.tandfonline.com/doi/abs/10.1080/07352166.2017.1360728

Slaughter, M. J. (2003). Host country determinants of U.S. foreign direct investment into Europe.” In Herrmann, H., and Lipsey, R. ed. Foreign direct investment in the real and financial sector of industrial countries. New York, NY: Springer, 7-32.

https://link.springer.com/chapter/10.1007/978-3-540-24736-4_2 
Thielemann, E. (2004). Does policy matter? On governments' attempts to control unwanted migration. CCIS Working Paper No. 112, University of California, San Diego.

Vernon, R. (1971). Sovereignty at bay: The multinational spread of U.S. enterprises. New York, NY: Basic Books.

https://onlinelibrary.wiley.com/doi/abs/10.1002/tie.5060130401

Whelan, F. G. (1983). Principles of U.S. immigration policy. University of Pittsburgh Law Review, 44, 447-484.

Williams, W. V. (1967). A measure of the impact of state and local taxes on industry location. Journal of Regional Science, 7, 49-57.

https://www.jstor.org/stable/2720085?seq=1\#metadata_info_tab_contents

Wong, C. (2006). Lobbying for inclusion: Rights politics and the making of immigration policy. Stanford, CA: Stanford University Press.

https://www.sup.org/books/title/?id=8383 


\section{Appendix 1. Summary of Major U.S. Immigration Laws}

\begin{tabular}{|c|c|}
\hline Year & Major highlights \\
\hline 1976 & $\begin{array}{l}\text { The Immigration and Nationality Act Amendments of } 1976 \text { (90 Stat. 2703) adopts the } 1965 \\
\text { Immigration and Nationality Act's system of immigration "preference categories" for } \\
\text { immigrants from Western Hemisphere countries. }\end{array}$ \\
\hline 1980 & $\begin{array}{l}\text { The Refugee Act of } 1980 \text { ( } 94 \text { Stat. 102) establishes a new statutory system for processing and } \\
\text { admitting refugees from overseas as well as asylum seekers physically present at US borders } \\
\text { or in the country. The law defines a "refugee" as any person outside the person's country of } \\
\text { nationality who is unable or unwilling to return to that country because of persecution or a } \\
\text { well-founded fear of persecution on account of race, religion, nationality, membership in a } \\
\text { particular social group, or particular opinion. }\end{array}$ \\
\hline 1986 & $\begin{array}{l}\text { The Immigration Reform and Control Act (IRCA) (100 Stat. 3359) provides for a } 50 \text { percent } \\
\text { increase in border patrol staffing, and imposes sanctions on employers who knowingly hire or } \\
\text { recruit unauthorized immigrants. The law also creates two legalization programs. One allows } \\
\text { unauthorized aliens who have lived in the United States since } 1982 \text { to regularize their status; } \\
\text { the other permits people who have worked for at least } 90 \text { days in certain agricultural jobs to } \\
\text { apply for permanent resident status. Under these programs, roughly } 2.7 \text { million people who } \\
\text { were then illegally residing in the United States eventually become lawful permanent } \\
\text { residents. }\end{array}$ \\
\hline 1994 & $\begin{array}{l}\text { The Violent Crime Control and Law Enforcement Act (VCCLEA) (108 Stat. 1791) gives the } \\
\text { US Attorney General the option to bypass deportation proceedings for certain alien aggravated } \\
\text { felons, enhances penalties for alien smuggling and reentry after deportation, and increases } \\
\text { appropriations for the Border Patrol. }\end{array}$ \\
\hline 1996 & $\begin{array}{l}\text { The Antiterrorism and Effective Death Penalty Act (AEDPA) (110 Stat. 1214) adds new } \\
\text { crimes to the definition of aggravated felony. AEDPA also establishes the "expedited } \\
\text { removal" procedure for arriving noncitizens who border official's suspect of lacking proper } \\
\text { entry documents or being engaged in fraud; the procedure is amended later that year by the } \\
\text { Illegal Immigration Reform and Immigrant Responsibility Act. }\end{array}$ \\
\hline 2001 & $\begin{array}{l}\text { The USA Patriot Act (115 Stat. 272) broadens the terrorism grounds for excluding aliens from } \\
\text { entering the United States and increases monitoring of foreign students. }\end{array}$ \\
\hline 2002 & $\begin{array}{l}\text { - The Enhanced Border Security and Visa Entry Reform Act (116 Stat. 543) requires the } \\
\text { development of an interoperable electronic data system to be used to share information } \\
\text { relevant to alien admissibility and removability. It also requires the implementation of an } \\
\text { integrated entry-exit data system: the US-VISIT program is established to implement this } \\
\text { system. } \\
\text { - The Homeland Security Act (116 Stat. } 2135 \text { ) creates the Department of Homeland Security } \\
\text { (DHS). In 2003, nearly all of the functions of the US Immigration and Naturalization Service } \\
\text { (INS) - the Department of Justice agency responsible for provision of immigration services, } \\
\text { border enforcement, and border inspection - are transferred to DHS and restructured to }\end{array}$ \\
\hline
\end{tabular}




\begin{tabular}{|c|l|}
\hline 2004 & $\begin{array}{l}\text { become three new agencies: US Customs and Border Protection (CBP), US Immigration and } \\
\text { Customs Enforcement (ICE), and US Citizenship and Immigration Services (USCIS). }\end{array}$ \\
\hline 2005 & $\begin{array}{l}\text { L-1 Visa Reform Act of 2004 added new penalties for abuse of the L-1 intra-company transfer } \\
\text { visa. }\end{array}$ \\
\hline $\begin{array}{l}\text { The REAL ID Act (119 Stat. 302) establishes statutory guidelines for removal cases, expands } \\
\text { the terrorism-related grounds for inadmissibility and deportation, includes measures to } \\
\text { improve border infrastructure, and requires states to verify an applicant's legal status before } \\
\text { issuing a driver's license or personal identification card that may be accepted for any federal } \\
\text { purpose. (States' protests persuade Congress to delay implementation of the drivers' license } \\
\text { provisions of the law.) It also bars the use of habeas corpus as a vehicle for challenging } \\
\text { removal orders, thus virtually completing the concentration of judicial review in the courts of } \\
\text { appeals. }\end{array}$ \\
\hline $\begin{array}{l}\text { Congress enacts the Secure Fence Act after the Senate fails to adopt immigration reform } \\
\text { legislation that had passed the House in 2005. The law mandates the construction of more than } \\
\text { 700 miles of double-reinforced fence to be built along the border with Mexico, through the US } \\
\text { states of California, Arizona, New Mexico, and Texas in areas that experience illegal drug } \\
\text { trafficking and illegal immigration. It authorizes more lighting, vehicle barriers, and border } \\
\text { checkpoints and requires the installation of more advanced equipment, such as sensors, } \\
\text { cameras, satellites, and unmanned aerial vehicles, in an attempt to increase control of illegal } \\
\text { immigration into the United States. }\end{array}$ \\
\hline
\end{tabular}

Source: Migration Policy Institute (https://www.migrationpolicy.org/research/timeline-1790) 


\section{Appendix 2. Path Coefficients Models}

Figure A1. Refugee Ceiling per Capita

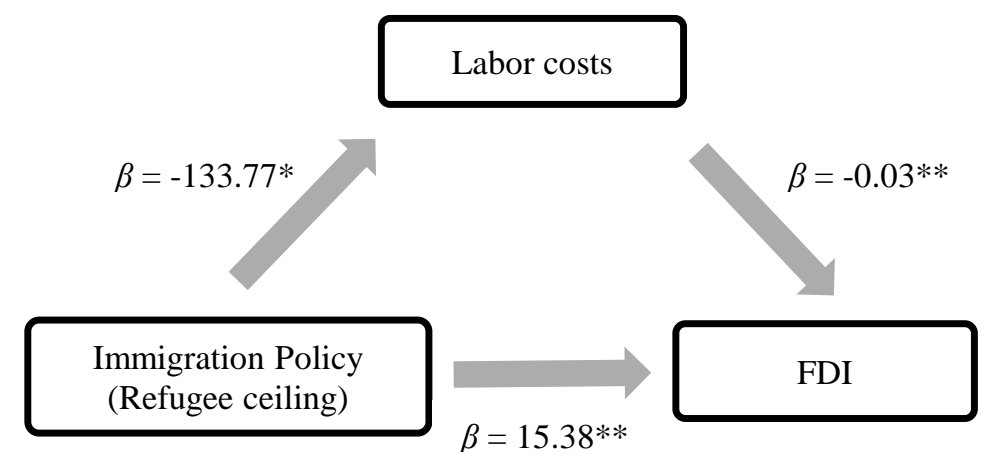

Figure A2. Restrictive Immigration Law

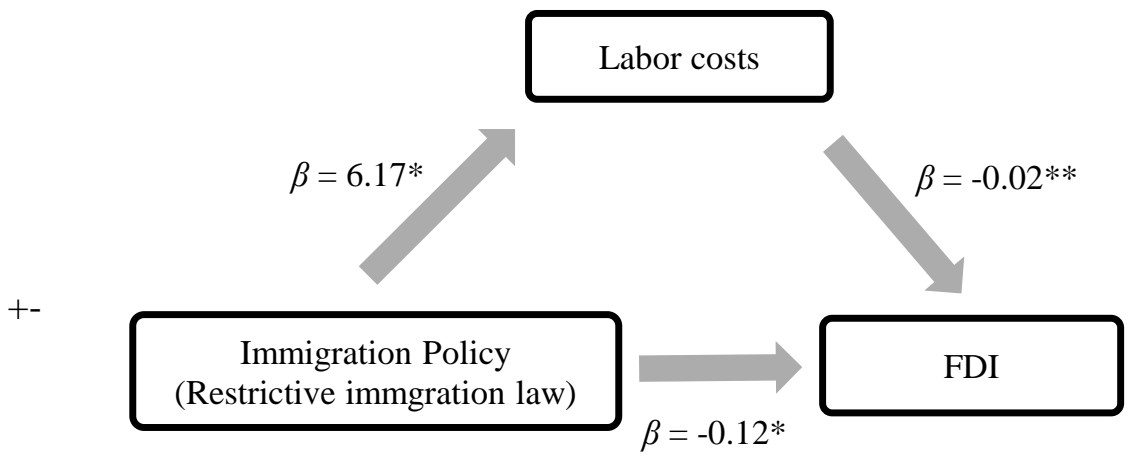

